\begin{tabular}{c} 
Volume and Issues Obtainable at Center for Sustainability Research and Consultancy \\
Sustainable Business and Society in Emerging Economies \\
ISSN: 2708-2504 ISSN (E) 2708-2172 \\
Volume 1: No. 2, December2019 \\
CSRᄃ \\
Journal homepage: $\underline{\text { www.publishing.globalcsrc.org/sbsee }}$ \\
\hline
\end{tabular}

\title{
Designing Business Model for Developing Micro Enterprise (Case Study Seluang Fish Fried of Ayakh Ugan)
}

\section{${ }^{1}$ Novy Anggraini, ${ }^{2}$ Rini Apriyani}

${ }^{1}$ Assistant Professor, Study Program of Management, Dwi Sakti Baturaja College of Economics, Indonesia: anggraininovy@gmail.com

${ }^{2}$ Assistant Professor, Study Program of Management, Dwi Sakti Baturaja College of Economics, Indonesia: riniapriyani99@yahoo.co.id

\begin{tabular}{l}
\multicolumn{1}{c}{ ARTICLE DETAILS } \\
\hline History \\
Revised format: November 2019 \\
Available Online: December 2019 \\
\hline Keywords \\
MSMEs, Micro Enterprise, \\
Canvas Business Model, Blue \\
Ocean Strategy
\end{tabular}

JEL Classification:

G21, E32, E39

\begin{abstract}
The purpose of this study was to describe a business model that can be applied to the Seluang Fish Fried product of the Ayakh Ugan brand in Baturaja, Indonesia. The data was collected by using an interview with the owner and observation. The results analysis with the mapping of the canvass business model and blue ocean strategy. The application of these two combinations generates an overview of new strategies that can be applied to increase sales. From the result can be concluded elements that play an important role and can be improved, namely the value proposition, channels, revenue streams, key activities, and cost structures. The second step that needs to be reduced is dependence on the connector. In the third step, there are no elements that need to be eliminated. Then the final step on the elements of the value proposition, customer relations, main resources, and cost structure are the points that need to be created. This research provides an overview of the mapping of business models that can be applied to micro business products. this study is useful for business owners in creating new strategies to expand marketing and increase sales through the results of mapping methods that can be improved and created from important elements. This result can also be taken into consideration for other micro business owners to apply to their businesses.
\end{abstract}

(C) 2019 The authors, under a Creative Commons AttributionNonCommercial 4.0

Corresponding author's email address: anggraininovy@gmail.com

Recommended citation: Anggraini, N. \& Apriyani, R., (2019). Designing Business Model for Developing Micro Enterprise (Case Study Seluang Fish Fried of Ayakh Ugan). Sustainable Business and Society in Emerging Economies, 1(2),81-92

DOI: $10.26710 /$ sbsee.v1i2.1111

\section{Introduction}

In the past decade, the presence of micro, small and medium enterprises (MSMEs) became important. At present, MSMEs have begun to be developed for a larger business scale because they are able to provide a sizeable contribution to a country's economic growth. In Asian developing countries, MSMEs have made 
significant contributions over the years measured in terms of their shares especially in: (a) number of enterprises; (b) employment generation; (c) production and value-added; (d) aggregate output or gross domestic product (GDP); (e) number of enterprises set up by women entrepreneurs; and (f) regional dispersal of industry. In developing coutries that have densely populated area like India, China, and Indonesia, the growth of MSMEs is also considered very important due to their potential contributions to employment creation, improvement of the income distribution, poverty reduction, export growth of manufactures, and development of manufacturing industry, rural economy, and entrepreneurship, especially among young educated individuals and women (Tambunan, 2011).

Data from Ministry of Cooperatives and Small and Medium Enterprises in 2013 explain that the MSME contribution toward the creation of national foreign exchange through non oil and gas exports experience the improvement amount about Rp50.35 trillion or 30.09\% that is about Rp189.46 trillion or $18.17 \%$ from the total export value of national non oil and gas exports. Data explain that the owners of MSME in Indonesia employ about 100,096,270 employees or $93.04 \%$ from the total employment in Indonesia (Kementerian Koperasi dan UMKM, 2017). Based on the HSBC survey, of the 51 million registered SMEs businesses, 37 percent of which will expand the business, 16 percent will increase the number of employees. This shows that SMEs have a large multiplier effect on the national economy. Also, approximately 60 percent of current GDP is related to the SMEs sector (Saefudin, Dinar, \& Nur, 2013).

MSMEs also have a very important role based on Urata (2000) in Rusdarti \& Kistanti (2018) who has observed the development of MSMEs confirms that MSMEs play some important role namely: (1) Employment provider (2) Important actors in local economic development and community development (3) Creator of market and innovation through flexibility and sensitivity as well as dynamic interconnection among company's activities (4) Contribute to the increase of non-oil exports. SMEs reduce income inequality (Rusdarti \& Kistanti, 2018) The government is currently very persistent to support the development of MSMEs which has impacts result in the emergence of new businesses with superior products in the regions and creative industries. In addition, many higher educations also support entrepreneurship. This is evidenced by the fact that entrepreneurship has been incorporated into curriculum studies at higher education and provides opportunities for college students to innovate in creating a business. Innovation in SMEs is to make changes and create value in the market to the community (Yanah, et.al., 2018).

According to Lestari (2013) there are several weaknesses of MSMEs in Indonesia such as management, organization, technology, capital, operational and technical aspects in the field, limited market access, licensing constraints, and non-technical costs in the field that are difficult to avoid. The SMEs engaged in developing countries normally produce traditional items (inferior quality) accompanied with low productivity. They mainly cater to the small local markets (Mukherjee, 2018). MSMEs face a number of problems: a) Lack of training, development and consultancy activities due to lack of information which they do not recognize the need for raising their production and growth. b) MSMEs find it hard to enter in a potentially competitive market. c) MSME faces an expensive and time-consuming regulatory requirement in licensing and registration. d) A legal requirement of the land of law prohibits their desired growth, for instance, a special status granted to certain states hinders them from entering into a highincome zone. e) Non-favourable and discriminatory tax structure. f) Rigid labour market regulations make hiring and firing difficult and expensive tends to prohibit the mobility of the workforce. g) Lack of infrastructure facilities, for example, transportation, market, and communication prohibits to access information and markets.

Some of the MSMEs do not have any strategic tools for their business/ market development as available with large industries. They do not correctly understand as to what a kind of product is actually needed by the market, how big or small is the market, when the products are needed and how to deliver such products. All these problems lead to the isolated from the market trends and conditions and, thus, tend to restrict the operations (Venkatesh \& Kumari, 2015). The management used is $67 \%$ lacking in business 
management and is still traditional and self-taught so that this has a difficult impact on their business development (Habiburahman, et.al., 2019), limited work capital and investment, difficulty in marketing, distribution and procurement of raw materials and other inputs, limited information access of market chances and other information, limited workers with high expertise and technology capability, high transportation and energy costs, limited communication access, high cost by complex administration and bureaucracy procedures mainly in business permit processing, indefinite or undirected clear condition as a result of unclear economic rules and policies (Kadin, 2008 in Supriaddin, et.al., 2018). Many MSMEs have not yet made use of E-commerce well despite awareness of its great potentials to develop and maintain the enterprises due to lack of insight and knowledge on the current developing technologies (Prameswari, et.al., 2017). Despite this, with the right strategy MSMEs can still develop and be able to compete with large companies. MSMEs in Indonesia have the opportunity to be succeeded at the international level as long as they have good quality and appropriate strategies against the challenge. MSMEs in Indonesia also has the potential to become the leading brands of the world, therefore the quality and competitiveness must be improved in both the local and international market (Rifai, et.al., 2016).

Ayakh Ugan is a micro-scale business that processes fish products into snacks that can be consumed by all people. The industrial scale applied is a micro-scale business. This industrial scale can be categorized into 4 namely home industry, micro industry, medium industry, and large industry (Umar, et.al., 2018). So to be able to compete in this industry, Ayakh Ugan must have a good business strategy. The success of a business, whether micro, medium, or large, depends on the characteristics of the business owner (Umar, et.al., 2018), the business model connects the company and the external business environment, customers, competitors, and society (Teece, 2010). From the very beginning, products with the Ayakh Ugan brand were quite popular, especially during the peak season, many local and national tourists bought up souvenirs in this place to take home or serve as snacks on the trip. On normal days, sales of products, especially for products made from Seluang fish are not very high. The reason is people usually know Belida fish or mackerel fish as processed food. In fact, Seluang fish also have a tasty, contain with high protein too, and the price is also affordable for people from all economic circles. The purpose of this study was to describe a business model that can be applied to the Seluang Fish Fried product of the Ayakh Ugan brand through the Canvass Business Model and Blue Ocean Strategy approaches so that this product can develop more widely.

\section{Methods}

In this research, the methods used are the Business Model Canvas (BMC) combined with the Blue Ocean Strategy (BOS) to map business strategies that can be applied by micro-businesses. BMC is used as a tool that provides a clear view of what companies need to achieve and focuses on the most important strategic elements and will have the greatest impact on business (Amanullah, et al., 2015). The perception of BOMS based on Ansoff's generic market development strategy brings a new perspective in marketing strategy by redefining the market competition and emerge as a substitute for an alternative simple traditional market-making (Chakrabarti, 2014).

\subsection{Data Collection Tchnique}

This research uses two types of data which are primary data and secondary data. Primary data obtained through two methods namely interview and field observation. The interview was done with the owner, a financial manager, and the production and marketing department of Ayakh Ugan and observation was carried out by observing the production process at Ayakh Ugan and the offline sales process at the store.

\subsection{Business Model Canvas (BMC)}

One approach strategy that can be used to measure business potential is the business model approach, one of them is Business Model Canvas (BMC). This methodology is broadly applicable to new companies, existing companies, non-profits and non-profit organizations (Gavrilova, et.al., 2014), and business 
advisor (Leschke, 2013). Osterwalder and Pigneur (2015) divide the Business Model Canvas into 9 important elements that must be analyzed include: customer segments, value propositions, channels, customer relationships, revenue streams, key resources, key activities, key partners, and cost structures, respectively separated again into two parts namely right (creative side) and left (logical side). The complete division of 9 elements of the business model is illustrated by one large canvas with the following stages of analysis:

- Customer Segments (CS): Who are your customers and why will they buy from you? What are your customer archetype. Know and understand your customers in detail.

- Value Proposition (VP): What product/service are you creating and for whom? What need are you filling? What problem are you solving? What pain, are you addressing?

- Channels $(\mathrm{CH})$ : How will your product/service get from you to your customers? Is your distribution channel virtual or physical?

- Customer Relationships (CR): How do you plan to acquire and retain customers? How will you get traffic to a website or to a physical location? How do you plan to grow your customer base?

- Revenue Streams (RS): How do you plan to make money? What value are customers buying?

- Key Resources (KR): What do you need to make the business work? What key assets do you need? People? Financing? Warehousing? Customer list?

- Key Activities (KA): What actions will you have to take to operate the business? What are the most important things to do to make the business work?

- Key Partnerships (KP): What activities will partners be performing? What are you acquiring from partners?

- Cost Structure (CS): What are the fixed and variable costs to operate the business? What are the most expensive activities? Are there economies of scales?

In principle, the BMC method is carried out to answer the 9 key elements sequentially based on the analysis of Ayakh Ugan products, then map it into the business canvas.

\subsection{Blue Ocean Strategy (BOS)}

There are four steps to the framework used in the Blue Ocean Strategy to create and reconstruct elements of buyer value, including: eliminate-reduce-enhance-create (Kim and Mauborgne, 2016) :

- Eliminate : What factors have been accepted by this product that must be eliminated

- Reduce : What factors must be reduced to below the product standard

- Enhance : What factors must be increased to above product standards

- Create : What factors must be created, which have never been offered by this product

The framework will answer some questions that arise then be analyzed based on the results of the initial BMC mapping. To get the final picture of the business model that can be developed by Ayakh Ugan, the results of the analysis from BOS are mapped back into BMC.

\section{Results}

The BMC is used to analyze the company's internal environment through 9 interrelated elements in a systematic and sequential manner starting from the first element to the last. Following are the results of an analysis of 9 elements BMC of Ayakh Ugan Seluang Fish Fried.

\subsection{Customer Segments}

Ayakh Ugan is a typical Baturaja souvenir food product that utilizes local wisdom so that the intended customers can be anyone interested in buying, individuals or companies, and from different groups, statuses, sexes, and ages. Buyers are generally people or companies who want to try South Sumatra 
special foods, especially Baturaja. Based on the grouping conducted by Ostewalder and Pigneur (2015), this type of customer is included in the category of open market (mass market) that does not differentiate each customer. In this market, everyone is a potential prospective buyer so anyone who needs this product will always be the focus of the company.

The business model adopted by Ayakh Ugan is Business to Business (B2B) and Business to Customer (B2C) so that customers who buy Ayakh Ugan products are divided into two, namely individuals/individuals and companies/organizations. B2B companies that work together to become agents of product distribution are retailers who sell products again to consumers, including UB Mart, 212Mart, Thai Tea, and City Mall, and other minimarkets in Baturaja. Customers who have purchased Ayakh Ugan products come from Baturaja, Java, Batam, and even Malaysia. Buyers from Baturaja usually buy directly to the marketing center (store) or through a retailer. For buyers who come from outside the area to order online through social media with a payment transfer system at the beginning with additional shipping costs.

\subsection{Value Proposition}

The value proposition will be an attraction for buyers for the products and services offered by a company so that it can meet customer satisfaction. This will give entrepreneurs more insight into how customers and products or services are connected, even allowing them to help design directly for the market and not beside them (Ching \& Fauvel, 2013). Ayakh Ugan has a novelty value proposition and presents it by offering products that do not exist in Baturaja yet by becoming a regional specialty souvenir, especially for Seluang fish fried products. With this novelty, Ayakh Ugan is able to set high prices on the market because the produced of products can give benefit to buyers as regional souvenirs. Ayakh Ugan's products have also been registered with BPOM and the Department of Health, making this product safe for consumption.

In addition, Ayakh Ugan provides a 10\% discount for purchases above Rp. 200,000 both through online and offline purchases, this promotion gives profit to customers. Whereas retail partners who work with Ayakh Ugan applied a payment system after the next order. This certainly provides benefits for both parties in increasing their respective sales.

\subsection{Channel}

In selling its products, Ayakh Ugan combines two marketing channels, by using their own media and working with partners. The use of media carried out by Ayakh Ugan through online social media such as Instagram, Facebook, and Whatsapp, and offline through a shop in the city center. Thus, using this media channel makes possible for companies to deal directly with buyers so that high trust can be created between the company and the buyer. Large sales opportunities can be obtained through integrated technology as E-commerce (Purnawati \& Setyohadi, 2017). Media partners who work with Ayakh Ugan in the form of shops and minimarkets in the Baturaja region.

\subsection{Customer Relationship}

The type of relationship used in this business is communities. Ayakh Ugan utilizes social media as a platform for promotional and sales media, at once building relationships with customers. Information about the company's products and activities can be followed at any time by customers who have joined the community as followers, in fact, customers can also interact directly with the company, either within or outside the city.

For certain customers such as retail or minimarket in the city, the type of relationship used is a dedicated personal assistant. This type of customer relationship is carried out in order to establish continuous cooperation and build trust between the company and partners, so the company sends its representatives directly to build this relationship. 


\subsection{Revenue Streams}

The current revenue of Ayakh Ugan comes from the sale of products which are produced as the main source, so the company's turnover is highly dependent on the number of sales per year through online and offline, and from partners who have worked together to sell products.

\subsection{Key Resources}

One of the keys to success in business is having the main resources that can support business activities and increase sales. The main resources owned by a business can be owned both alone or through leases with third parties. The main resources owned by Ayakh Ugan include:

- Physical facilities namely: houses used as production sites, store used as marketing places, cars used as delivery vehicles, laptops, and equipment used in the production process.

- Human resources work as assets for business success. Workers in Ayakh Ugan are experienced workers who have been trained so that they are able to produce and sell the products.

- The capital available at Ayakh Ugan was initially only IDR 2.500 .000 because it was still included as a micro business. However, along with increasing public knowledge about this business, it is able to increase capital to be large. The monthly sales reach IDR 20.000.000, so the annual turnover is about Rp. 240,000,000. The increase in turnover can increase the amount of capital in order to make the business stable over the next several periods.

\subsection{Key Activities}

The main resources are closely related to the key activities of this business. The key activity of this business lies in the production section because this part produces all the products that will be sold by Ayakh Ugan. These production activities include weeding, drying, frying, and packaging.

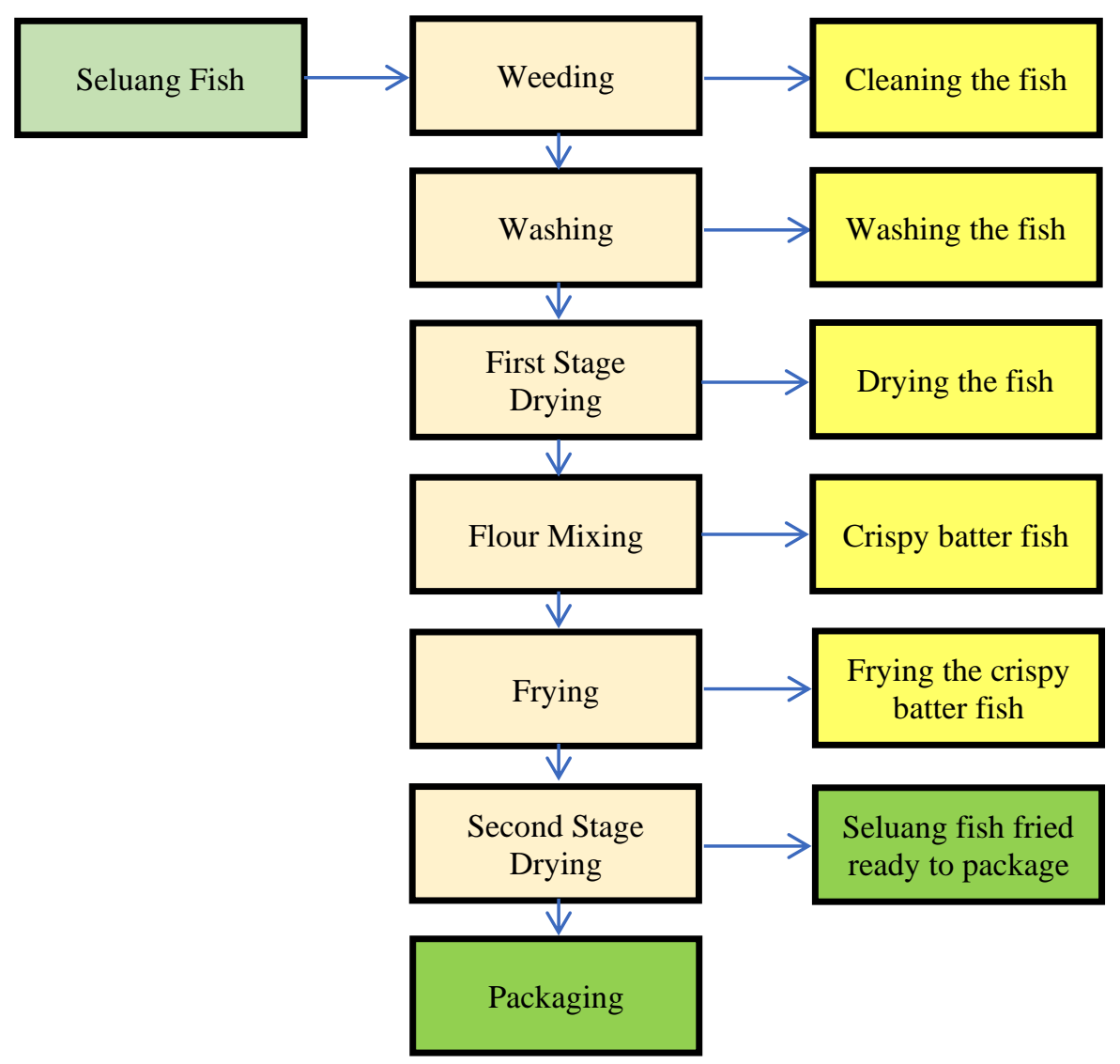

Figure 1. Flowchart Production Process 
- Weeding: This is the process for removing or cleaning the gills, scales and digestive organs of fish. In this process, some employees will only use a small knife.

- Washing: This process is done as in general clean the fish, which is by spraying enough water using a hose so that the fish is clean from the dirt and the remnants of blood that may be attached.

- First Stage Drying: The purpose of drying is to reduce the moisture content of the material to the limits of the microorganism's growth and enzyme activities that can cause decay inhibited or even stopped altogether. The tool used is a spinner for approximately 10 minutes.

- Flour Mixing: This process is an important process to make the fish become a unique product so this can provide value-added for buyers, namely the process of mixing flour. In this process, the fish is mixed with tapioca flour mixed with a little salt and baking soda. This process makes the fish tasty and delicious.

- Frying : Frying, in general, is a way to cook food using oil, or fat (margarine, shortening, or butter) as a medium for conducting heat. Fat is the same as oil, it only differs because of different melting points. Curing is a food processing that is much in demand by consumers because it can improve the taste and texture of food so that food becomes more crispy. The recommended frying temperature is $177-201$ oC.

- Second Stage Drying: The purpose of the second stage drying is to reduce the levels of cooking oil in the material that has been cooked. The execution of this process takes the same time as the first stage which is 10 minutes by using a spinner.

- Packaging : The packaging is the activity of designing and producing packaging or packaging for products. The main function of packaging is to maintain product quality. However, packaging has become an important factor as a marketing tool used to be able to attract the attention of consumers now. The packaging process of Ayakh Ugan is still very simple with a packaging design that is also plain, using both plastic and cans that are online ordered from the other city.

\subsection{Key Partnership}

In developing businesses, every company must have partners who make the business run smoothly and minimize existing risks or facilitate the supply of raw materials. the types of partnerships that companies run according to Osterwalder and Pigneur (2015) are strategic alliances between non-competitors, coopetition (strategic partnerships between competitors), joint ventures to develop new businesses, as well as buyer and supplier relationships to guarantee reliable supplies.

Ayakh Ugan has two permanent supplier agents for fish raw materials in order to facilitate the production process and overcome the availability of raw materials. For packaging raw materials, Ayakh Ugan also has online raw material suppliers from outside the city, namely Palembang and Java. Company performance in micro business can be improved by product and service innovations through collaboration with suppliers (Chiayu, 2014). In addition to suppliers of raw materials, partners in marketing also play an important role. Ayakh Ugan has collaborated with several retailers in the city to increase sales. This gives its own advantages for businesses in efforts to expand marketing and product introduction to the public.

\subsection{Costs Structure}

Costs expenses in this business have not been too large because it is still classified as a micro-scale. In this effort, there are fixed costs and variable costs as formulated by Osterwalder and Pigneur (2015). Details of monthly expenditure can be seen in the following Table 1. 
Table 1. Ayakh Ugan Cost Expenditures in May 2019

\begin{tabular}{|c|c|c|c|}
\hline Item & $\begin{array}{c}\text { Item } \\
\text { Number }\end{array}$ & Costs (IDR) & $\%$ \\
\hline \multicolumn{4}{|c|}{ Variable Cost $=\mathbf{7 8 , 0 6 \%}$} \\
\hline Seluang Fish & $300-350 \mathrm{~kg}$ & 13500000 & 52,43 \\
\hline Kentucky Flour & $300-350 \mathrm{~kg}$ & 2000000 & 7,77 \\
\hline Salt & 1-2 pack & 50000 & 0,19 \\
\hline Cooking Oil & 13 box & 3000000 & 11,65 \\
\hline Plastic Packaging & $10 \mathrm{~kg}$ & 700000 & 2,72 \\
\hline Cans Packaging & $100 \mathrm{pcs}$ & 700000 & 2,72 \\
\hline Freight Costs of Raw Material & & 150000 & 0,58 \\
\hline Item & $\begin{array}{c}\text { Item } \\
\text { Number }\end{array}$ & Costs (IDR) & $\%$ \\
\hline \multicolumn{4}{|c|}{ Fixed Cost $=21,94 \%$} \\
\hline Overtime Pay & & 150000 & 0,58 \\
\hline Electricity Costs For Production Houses & & 600000 & 2,33 \\
\hline Electricity Costs For The Store & & 150000 & 0,58 \\
\hline Gasoline Cost & & 100000 & 0,39 \\
\hline Online Promotion Fee & & 100000 & 0,39 \\
\hline Costs For Permanent Employee Pay & & 2300000 & 8,93 \\
\hline Costs For Daily Employee Pay & & 1500000 & 5,83 \\
\hline Costs For Machine Maintenance & & 500000 & 1,94 \\
\hline $\begin{array}{l}\text { Holiday Allowance For Permanent } \\
\text { Employees }\end{array}$ & & 150000 & 0,58 \\
\hline $\begin{array}{l}\text { Holiday Allowance For Daily } \\
\text { Employees }\end{array}$ & & 100000 & 0,39 \\
\hline \multicolumn{2}{|l|}{ TOTAL } & 25750000 & 100 \\
\hline
\end{tabular}

Table 1 shows that the variable costs are used to buy raw material for Seluang fish, Kentucky flour, salt, vegetable oil, plastic and canned packaging, and freight costs for raw materials. While fixed costs include the costs of permanent and daily employee payment, overtime pay, electricity for a production house and a store, gasoline, online promotions, Holliday allowance, and machine maintenance costs. The highest percentage of variable costs are found in the main raw material, namely fish Seluang at $52.43 \%$, while the fixed costs are paid for permanent employees (8.93\%) and daily $(5.83 \%)$. In the breakdown of these costs, it is also seen that the percentage of variable costs $(78.06 \%)$ is greater than the fixed costs $(21.94 \%)$. Thus, the cash flow turnover in this business is high so that this business can be run well.

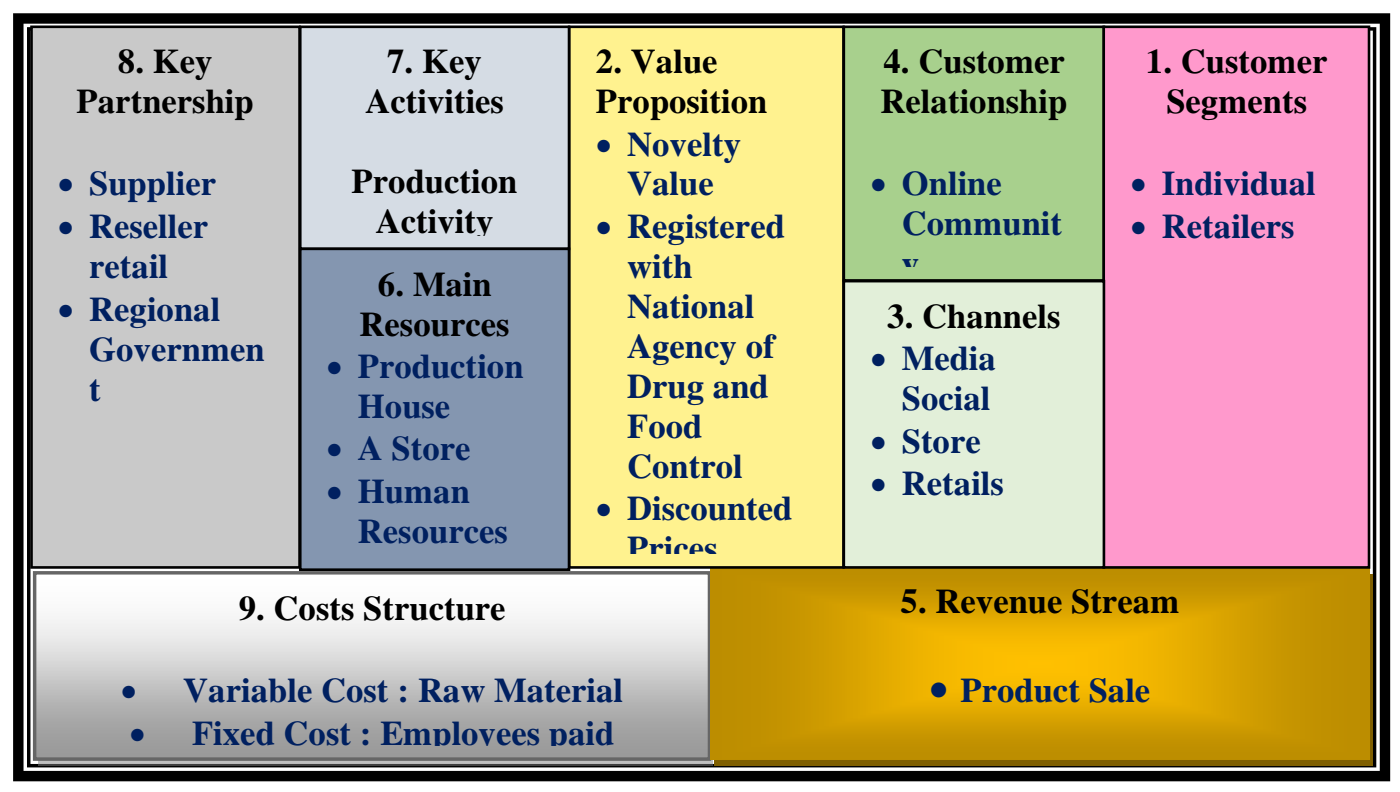

Figure 2. Canvas Model Design from BMC Analysis 


\subsection{Blue Ocean Strategy (BOS)}

The Blue Ocean Strategy is a free competition strategy in which businesses create their own niche by ignoring competitors (Chakrabarti, 2014). By applying the BOS method into BMC a new strategy will be formed which is expected to be able to create a new method that does not have competitors yet. The elements used in the BOS method are not all necessary, only a few elements are considered to renewal needed. The results of this combination of methods can be seen in Table 2 with the lines of attachment to each other.

Table 2. The Combination Methods Between BMC and BOS

\begin{tabular}{|c|c|c|c|c|}
\hline BMK & RAISE & REDUCE & ELIMINATE & CREATE \\
\hline $\begin{array}{l}\text { VALUE } \\
\text { PROPOSITION }\end{array}$ & $\begin{array}{c}\text { Sample for } \\
\text { online buyer }\end{array}$ & & & $\begin{array}{l}\text { Attractive plastic } \\
\text { packaging design }\end{array}$ \\
\hline CHANNEL & $\begin{array}{l}\text { Online marketing } \\
\text { through website, } \\
\text { market place, e- } \\
\text { commerce }\end{array}$ & $\begin{array}{l}\text { Depends on } \\
\text { relatives }\end{array}$ & & 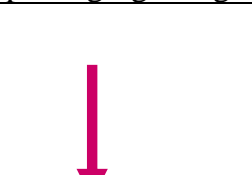 \\
\hline \multirow{4}{*}{$\begin{array}{l}\text { CUSTOMER } \\
\text { RELATIONSHIP }\end{array}$} & $\hat{1}$ & & & \multirow{4}{*}{\begin{tabular}{|c|} 
Introducing \\
products to the \\
public by using \\
famous people in \\
instagram or \\
regional pageant \\
$\begin{array}{c}\text { Membership, } \\
\text { reward or } \\
\text { giveaway }\end{array}$ \\
\end{tabular}} \\
\hline & & & & \\
\hline & & & & \\
\hline & & & & \\
\hline $\begin{array}{l}\text { REVENUE } \\
\text { STREAM }\end{array}$ & \multirow[t]{2}{*}{ Revenue increase } & & & \\
\hline $\begin{array}{l}\text { KEY } \\
\text { RESOURCES }\end{array}$ & & & & Fish dryer \\
\hline $\begin{array}{l}\text { KEY } \\
\text { ACTIVITIES }\end{array}$ & $\begin{array}{l}\text { Employee } \\
\text { increase }\end{array}$ & & & \\
\hline \multirow{2}{*}{$\begin{array}{l}\text { COSTS } \\
\text { STRUCTURE }\end{array}$} & \multirow{2}{*}{$\begin{array}{l}\text { Variable and } \\
\text { fixed costs } \\
\text { increase }\end{array}$} & & 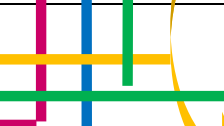 & \multirow[t]{2}{*}{$\begin{array}{c}\text { Website creation, } \\
\text { join market } \\
\text { place. }\end{array}$} \\
\hline & & & & \\
\hline
\end{tabular}

From the results of the early mapping of the BMC method, it can be performed an analysis of several BMC elements with the 4-step BOS method. The elements that play an important role and can be improved are in the value proposition, channels, revenue streams, key activities, and cost structures. The second step that needs to be reduced is dependence on the liaison. Then the final step on the elements of the value proposition, customer relations, main resources, and cost structure are the points that need to be created.

The combination of the two methods creates an addition strategy to the value proposition by creating packages that are more attractive to consumers and also more attractive to sell online. In addition, the customer relationship is very important to create a method that brings the seller closer to the customer so that customers feel more special and know what products are sold. Furthermore, also in the main resource section, namely fish dryer which is more sophisticated, this is also related to investment in the cost structure. The most important thing in online marketing is a website that is an alternative buyer in knowing and buying products. Therefore, it is very important for the seller to create a special website that 
has its own domain so that it is easier to reach buyers anywhere without any attachment to any social media network. Thus the canvas design of the model from the combined results can be seen in the following Figure 3.

\begin{tabular}{|c|c|c|c|c|}
\hline \multirow[t]{2}{*}{$\begin{array}{l}\quad \text { 8. Key } \\
\text { Partnership } \\
\text { - } \text { Supplier } \\
\text { - Reseller retail } \\
\text { - Regional } \\
\text { Government }\end{array}$} & $\begin{array}{l}\text { 7. Key Activities } \\
\text { Production } \\
\text { Activity }\end{array}$ & \multirow{2}{*}{$\begin{array}{l}\text { 2. Value } \\
\text { Proposition } \\
\text { - Novelty Value } \\
\text { - Registered with } \\
\text { National } \\
\text { Agency of Drug } \\
\text { and Food } \\
\text { Control } \\
\text { - Discounted } \\
\text { Prices } \\
\text { - Attractive } \\
\text { Packaging } \\
\text { Design } \\
\text { - Give } \\
\text { Sample/Product } \\
\text { Tester }\end{array}$} & $\begin{array}{l}\text { 4. Customer } \\
\text { Relationship } \\
\text { - Online } \\
\text { Community } \\
\text { - Membership } \\
\text { - Rewards } \\
\end{array}$ & \multirow[t]{2}{*}{$\begin{array}{l}\text { 1. Customer } \\
\text { Segments } \\
\text { - Individual } \\
\text { - Retailers }\end{array}$} \\
\hline & $\begin{array}{l}\text { 6. Main } \\
\text { Resources } \\
\text { - Production } \\
\text { House } \\
\text { - A Store } \\
\text { - Human } \\
\text { Resources } \\
\text { - Production } \\
\text { Equipmnets }\end{array}$ & & $\begin{array}{ll} & \text { 3. Channels } \\
\text { - Media Social } \\
\text { - Store } \\
\text { - Retails } \\
\text { - Ecommerce } \\
\text { - Website }\end{array}$ & \\
\hline \multicolumn{3}{|c|}{ 9. Costs Structure } & \multicolumn{2}{|c|}{ - Product Sale } \\
\hline
\end{tabular}

The results of this BMC design can be applied by the owner to develop his business and expand business marketing to be able to increase turnover and is expected to continue to grow and become a small scale business which then becomes large.

\section{Conclusion}

Based on the results of 9 elements of BMC that have been carried out, it can be seen that in developing its business, Ayakh Ugan needs to create several new strategies, especially for the product of Seluang Fish Fried in addition to existing strategies. Especially in introducing this product to consumers, innovation is needed in promotions that can attract potential buyers. The use of technology also needs to be improved, both as a promotional media and in building community networks. In the production process also needed the latest tools so that production activities can run on time and be able to reduce existing fixed costs. Support from the Regional Government also plays an important role as a form of promotion and introduction of products to the community inside and outside the city, and there needs to be an increase in cooperation with third parties or retailers. To be able to expand the marketing area, in addition to online marketing, collaboration with out-of-town retailers and large retailers that are known nationally is also needed.

The methods used are too simple, additional methods are needed to make other alternative choices that are better targeted and a deeper and global analysis of the external environment that can affect micro businesses, especially in Indonesia. In addition, in this business it is recommended for business owners to apply BMC in the financial department so that the revenue flow and business cost structure can be controlled and even increase business revenue. Empirical studies need to be done with a number of existing micro businesses so that results can be generalized and the methods used also apply to all micro businesses. 


\section{Acknowledgement}

This research sponsored by Grant Program of the Beginner Lecturer Research, Directorate of Research and Community Service, Directorate General of Research and Development Strengthening, Ministry of Research, Technology and Higher Education in Indonesia.

\section{References}

Amanullah, A., Azhana, A. N., Ab Aziz, N. F., Hadi, A., Hanis, N., \& Ibrahim, J. (2015). Comparison of Business Model Canvas (BMC) among the three consulting companies. International Journal of Computer Science and Information Technology Research, 3(2), 462-471.

Chakrabarti, M. (2014). Blue ocean marketing strategy (BOMS): An overview. Abhinav International Monthly Refereed Journal of Research in Management \& Technology, 3(5), 44-53.

Chiayu, T. (2014). How does cooperation affect innovation in micro-enterprises? Management Decision, 52(8), 1390-1409. https://doi.org/10.1108/MD-07-2013-0388

Ching, H. Y., \& Fauvel, C. (2013). Criticisms, Variations And Experiences With Business Model Canvas. European Journal of Agriculture and Forestry Research, 1(2), 26-37.

Gavrilova, T., Alsufyev, A., \& Yanson, A.-S. (2014). Modern Notation of business models: a visual Trend. Journal Foresight Russia, 8(2 (eng)), 56-71.

Habiburahman, Alam, I. A., \& Dunan, H. (2019). MSMEs Empowerment and Development Strategy Model. Review of Integrative Business and Economics Research, 8(2), 324-332.

Leschke, J. (2013). Business model mapping: A new tool to encourage entrepreneurial activity and accelerate new venture creation. Journal of Marketing Development and Competitiveness, 7(1), $18-26$.

Lestari, R. (2013). Perbankan Syariah Sebagai Daya Pendorong Usaha Mikro Kecil Menengah di Indonesia. Sustainable Competitive Advantage (SCA), 3(1), 1-11.

Mukherjee, S. (2018). Challenges to Indian micro small scale and medium enterprises in the era of globalization. Journal of Global Entrepreneurship Research, 8(1), 28-47.

Ostewalder A, Pigneur, Y. (2015). Business Model Generation. PT Elex Media Komputindo. Jakarta.

Prameswari, N., Suharto, M., \& Afatara, N. (2017). Developing E-Commerce for Micro Small Medium Enterprise (MSME) to Cope with Cultural Transformation of Online Shopping. Jurnal Dinamika Manajemen, 8(2), 188-198. https://doi.org/10.15294/jdm.v8i2.12759

Purnawati, N. W., \& Setyohadi, D. B. (2017). The Analysis of Implementation Business Model Canvas At The E-Marketplace Dipeta Company. Scientific Journal of Informatics, 4(2), 125-133.

Rifai, M., Indrihastuti, P., Sayekti, N. S., \& Gunawan, C. I. (2016). Strategy in Enhancing the Competitiveness of Small and Medium Enterprises in ASEAN Free Trade Era. International Journal of Academic Research in Business and Social Sciences, 6(12), 76-87.

Rusdarti, R., \& Kistanti, N. R. (2018). How to Enhance MSMEs Readiness? an Empirical Study in Semarang Municipality. JEJAK: Jurnal Ekonomi Dan Kebijakan, 11(1), 108-122.

Saefudin, Dinar, \& Nur, A. (2013). Indonesia Preparation Efforts in Dealing AEC 2015 Through Revitalization. Economics Development Analysis Journal, 2(2).

Supriaddin, N., Abbas, B., Razak, A., Anaam, N., \& Muthalib, D. A. (2018). Marketing Strategy Of Micro Small And Medium Enterprises (MSME) In The Framework Of Public Welfare Improvement In Southeast Sulawesi Province. International Journal of Scientific \& Engineering Research, 9(1), 933-937.

Tambunan, T. T. H. (2011). Development of micro, small and medium enterprises and their constraints: A story from Indonesia. Gadjah Mada International Journal of Business, 13(1), 21-43. https://doi.org/https://doi.org/10.22146/gamaijb.5492

Teece, D. J. (2010). Business models, business strategy and innovation. Long Range Planning, 43(2-3), 172-194.

Umar, A., Sasongko, A. H., \& Aguzman, G. (2018). Business model canvas as a solution for competing strategy of small business in Indonesia. International Journal of Entrepreneurship, 22(1), 1-9.

Venkatesh, J., \& Kumari, R. L. (2015). Role of Marketing Strategies in the Context of MSME Sector. 
International Journal of Research in Finance and Marketing, 5(8), 1-6.

Yanah, Y., Nakhwatunnisa, H., \& Sukarno, T. A. (2018). Strategy to Increase the Competitiveness of SME’s Entreprises. JEJAK: Jurnal Ekonomi Dan Kebijakan, 11(1), 138-150. 